\title{
The role of Qa-2, the functional homolog of HLA-G, in a Behcet's disease-like mouse model induced by the herpes virus simplex
}

\author{
Meeyoung Lee ${ }^{+1}$, Bunsoon Choi¹, Hyuk Jae Kwon¹, Ju A Shim¹, Kyung Sook Park2, Eun-So Lee ${ }^{3}$ and \\ Seonghyang Sohn*1,4
}

\begin{abstract}
Background: It has been suggested that the HLA-G molecule is a genetic risk factor for Behcet's disease (BD). In this study, we evaluated the level of Qa-2, a murine nonclassical class I MHC molecule and possible functional homolog of $H L A-G$, to determine if it was associated with various symptoms of BD-like mice. In addition, we investigated siRNA (small interfering RNA) treatment to determine if it inhibited Qa-2 expression, thereby changing the symptoms of mice.

Methods: RNA interference (RNAi) and vector transfection were employed to manipulate gene expression in vivo in mice. siRNA (small interfering RNA) or Qa-2 expression vector was applied to inhibit or up-regulate Qa-2 expression, respectively.

Results: The Qa-2 levels in granulocytes were lower in BD-like mice than in normal controls. The silencing of Qa-2 by intravenous injection of siRNA (500 nmol/mouse, 4 times at 3-day intervals) specifically reduced the Qa-2 levels and worsened the BD-like symptoms.
\end{abstract}

Conclusions: Silencing Qa-2 by injecting siRNA into mice resulted in deterioration of symptoms in BD-like mice.

\section{Background}

Since HLA-G (human leukocyte antigen-G) was first detected by Geraghty et al. [1], it has been reported that HLA-G protein is expressed at the feto-maternal interface during pregnancy [2] and on a subset of thymic epithelial cells [3], and that it is also involved in maintenance of tolerance of the maternal immune system toward the semi-allogeneic fetus. HLA-G is also expressed in other tissues such as intestinal mucosa [4] and PBMC [5]. Numerous studies have evaluated the relevance of HLA$\mathrm{G}$ under pathologic conditions such as transplantation, autoimmunity, cancer, and hematologic malignancies [6]. HLA-G interacts with different natural killer (NK) cell receptors and is able to inhibit NK and T-cell cytotoxicity, as well as T-cell proliferation [7]. Interestingly, HLA-G has been described as a unique ligand of the killer cell inhibitory receptor, KIR2DL4, which is expressed on the

\footnotetext{
* Correspondence: sohnsh@ajou.ac.kr

1 Laboratory of Cell Biology, Ajou University Institute for Medical Sciences,

Suwon, Korea

+ Contributed equally

Full list of author information is available at the end of the article
}

surface of all NK cells [8]. Furthermore, HLA-G inhibits the transendothelial migration of NK cells [9], shifts the cytokine balance toward Th2 dominance [10], and suppresses the proliferation of allogeneic $\mathrm{CD}^{+} \mathrm{T}$ lymphocytes $[11,12]$. Taken together, HLA-G exerts specific inhibitory effects against immune cells. In addition, recent studies indicate unexpected expression of HLA-G proteins in chronic cutaneous inflammatory diseases, such as psoriasis [13] and atopic dermatitis [14].

Behcet's disease (BD) is a chronic multi-systemic disorder that involves the gastrointestinal, mucocutaneous, ocular, vascular, central nervous, and articular systems. $\mathrm{BD}$ has a chronic course that includes periodic exacerbations and progressive deterioration [15]. Although the etiology of BD is unclear, viral infection has long been postulated as one of its main factors. The viral hypothesis has been verified by detection of the virus in saliva [16], intestinal ulcers [17], and genital ulcers [18] of patients with BD since it was first proposed by Hulûsi Behçet [19]. Furthermore, inoculation of the earlobe of ICR mice with herpes simplex virus (HSV) enables development of a 
BD-like animal model [20]. Manifestations in mice following HSV inoculation involve multiple symptoms such as oral ulcers, genital ulcers, skin ulcers, eye symptoms, gastrointestinal ulcers, arthritis, and neural involvement, as well as skin crusting. The frequency of these symptoms is similar to that of patients with BD [21]. In addition to viral causes of BD, several studies have identified lymphocyte dysfunction as a possible cause $[22,23]$. Thus, attention has been focused on the T helper (Th) 1 and Th2 cytokines, with Th1 cells perhaps playing a more important role in the immunopathogenesis of BD [24]. When the Th2 adjuvant, aluminium hydroxide (alum), was mixed with ovalbumin (OVA) and injected into mice suffering from $\mathrm{BD}$, their cutaneous symptoms were improved [25].

Park et al. [26] reported that the frequency of haplotypes containing a HLA-G 3741_3754 14 base pair insertion and $1597^{*}$ delC was increased in BD patients. Moreover, individuals who were homozygous with the 3741_3754*ins14/"ins14 genotype were found to have a risk of $\mathrm{BD}$ that was 2.7-times greater than that of the controls. The HLA-G $3741^{*}+14 \mathrm{bp}$ induces a significantly lower expression level than the complete HLA-G mRNA isoforms. In addition, the HLA-G 3741_3754 14-base pair insertion allele was found to occur significantly more frequently in BD patients with ocular, arthritis, and CNS symptoms than in controls, and this insertion was found to be related to the lower serum level of HLA-G [26]. The authors who presented these findings suggested that these HLA-G allelic variants are genetic risk factors for BD. In addition, the HLA-G*010101 alleles have been shown to have a significantly lower frequency in $\mathrm{BD}$ patients than in control subjects [27].

As a result, it is important to determine if HLA-G contributes to the pathogenesis of BD. To accomplish this, Qa-2 expression, the functional homolog of HLA-G in mice, was identified and modulated by small interfering RNA (siRNA) and the Qa-2 expression vector. The results of this study confirmed that decreased Qa-2 levels are related to changes in the disease pattern and deterioration of BD-like symptoms.

\section{Methods}

Animals, induction of BD-like symptoms, and scoring of BD activity

Five-week-old ICR male mice were used in this study. To induce a BD-like disease in mice, their earlobes were scratched with a needle and then inoculated with $1.0 \times$ $10^{6}$ plaque forming units $/ \mathrm{ml}$ of HSV type 1 (F strain). Virus inoculation was performed twice with a 10-day interval, after which the mice were observed for 30 weeks. Mice were housed in conventional temperatureand light-controlled rooms $\left(20-22^{\circ} \mathrm{C}, 12 \mathrm{~h}\right.$ light cycle starting at 8:00 a.m.) and had free access to food and water. During the experiment, the animals were observed closely. Mice were handled in accordance with the protocols approved by our institutional animal care committee. Manifestations in mice after HSV inoculation involved multiple symptoms including oral ulcers, genital ulcers, skin ulcers, eye symptoms, intestinal ulcers, arthritis, and neural involvement, as well as skin crusting. Oral, genital, and other skin ulcers (including bulla and crust), and eye symptoms were all classified as major symptoms, while other symptoms were classified as minor symptoms [20]. Overall, $15 \%$ of the HSV-injected mice developed BD-like symptoms. The disappearance of symptoms and decrease in lesion size constituted an improvement, similar to in human patients.

The animals were observed once a week after HSV inoculation, at which time the severity of BD was determined according to the $\mathrm{BD}$ activity index, as outlined in the Behcet's Disease Current Activity Form 2006 http:// www.behcet.ws/pdf/BehcetsDiseaseActivityForm.pdf.

The occurrence of the following symptoms in the mouse model were selected for analysis: mouth ulceration, genital ulceration, erythema, skin pustules, skin ulceration, joints-arthritis, diarrhea, red eye (right, left), reduced vision (right, left), loss of balance, discoloration, and swelling of the face. The score of each symptom was one, and the total score before and after treatment was used to determine the severity of BD. Mice exhibiting significantly reduced symptoms were photographed to document improvement after treatment.

\section{Synthesis and in vitro test of siRNA}

Qa-2 siRNA oligonucleotides with the following sense and anti-sense sequences were designed and synthesized by Dharmacon (Chicago, IL, USA). The Qa-2 protein was encoded by four genes in the Q region, Q6, Q7, Q8 and Q9. These genes have a typical class I MHC gene structure involving exon 1 (leader peptide), exon $2(\alpha 1$ domain), exon 3 ( $\alpha 2$ domain), exon 4 ( $\alpha 3$ domain), exon 5 (transmembrane domain), and exons 6, 7 and 8 (cytoplasmic domains). As shown in Table 1, we selected four sequences located in each domain to synthesize siRNA. To confirm the function of interference, the synthesized siRNA was tested in vitro in peripheral blood mononuclear cells (PBMC). To accomplish this, PBMCs were isolated from 5-6 week-old ICR mice and cultured at $1 \times 10^{5}$ cells $/ \mathrm{ml}$ in DMEM medium with $1 \%$ antibiotics and $10 \%$ FBS. siRNA (200 nM) was incubated with $3 \mu \mathrm{L}$ of oligofectamin (Gibco-Invitrogen, Rockville, MD) in $200 \mu \mathrm{L}$ of DMEM medium. After $24 \mathrm{~h}$ of treatment with siRNA, the PBMCs were harvested and subjected to RT-PCR.

\section{In vivo siRNA injection}

For application to mice, $500 \mathrm{nM}$ of siRNA in $200 \mu \mathrm{L}$ of $5 \%$ glucose, including transfection reagent jetPEI (Polyplus, 
Table 1: Qa-2 siRNA oligonucleotide sequences

\begin{tabular}{|c|c|}
\hline Qa-2 domain & siRNA oligonucleotides sequences \\
\hline $\begin{array}{l}\text { Leader peptide } \\
\text { domain }\end{array}$ & $\begin{array}{l}\text { 5'-CAACACUCGCAAUAUU-3'(sense) } \\
\text { 3'-GUUGUGAGCGACGUUAUAA-5'(antisense) }\end{array}$ \\
\hline a3 domain & $\begin{array}{l}\text { 5'-AGGUCUUAUGGUGCUGUCAUU-3'(sense) } \\
\text { 3'-UUUCCAGAAUACCACGACAGU- } \\
\text { 5'(antisense) }\end{array}$ \\
\hline $\begin{array}{l}\text { Transmembrane } \\
\text { domain }\end{array}$ & $\begin{array}{l}\text { 5'-UGUGAUGAAUAGGAGGUGAUU-3'(sense) } \\
\text { 3'-UUACACUACUUAUCCUCCACU- } \\
\text { 5'(antisense) }\end{array}$ \\
\hline $\begin{array}{l}\text { Cytoplasmic } \\
\text { membrane domain }\end{array}$ & $\begin{array}{l}\text { 5'-UAGAGCUCUGAUAGAUCUCUU-3'(sense) } \\
\text { 3'-UUAUCUCGAGACUAUCUAGAG- } \\
\text { 5'(antisense) }\end{array}$ \\
\hline
\end{tabular}

France, Illkirchcedex), was intravenously injected into mice one to four times with a three day interval between injections. Two-days after the last injection, mice were photographed and the PBMCs were analyzed using a fluorescence-activated cell sorter (FACS). The control group was injected with $200 \mu \mathrm{L}$ of $5 \%$ glucose. Qa-2 leader peptide domain siRNA did not down-regulate the Qa-2 mRNA level in in vitro PBMC cultures when compared to other domains; therefore, the leader peptide domain siRNA was injected as a control. For in vivo administration to mice, $1.5 \mu \mathrm{L}$ of transfection reagent was mixed with $5 \%$ glucose and siRNA. The Qa-2 siRNA was mixed with $\alpha 3$ domain, transmembrane domain and cytoplasmic domain in equal amounts, after which it was administered to mice.

\section{Flow cytometry}

To analyze the Qa-2 expression, cells were harvested and fixed with $4 \%$ formaldehyde in $1 \%$ fetal bovine serum containing PBS for $20 \mathrm{~min}$ at room temperature, after which they were incubated with FITC-conjugated antiQa-2 antibody (eBioscience, San Diego, CA, USA). Stained cells were analyzed in FACS Vantage using the Cell Quest software (Becton Dickinson, Franklin Lakes, NJ, USA) by collecting at least 10,000 gated lymphocytes [7].

\section{Reverse transcription PCR (RT-PCR)}

Total RNA was isolated using TRIzol (Life Technologies, Helgerman, CT) according to the manufacturer's recommendations. Two $\mu \mathrm{g}$ of total RNA were used as a template for cDNA synthesis, which was conducted using a SuperScript III First-Strand Synthesis System for RT-PCR kit (Invitrogen, Carlsbad, CA). The cDNA was amplified by PCR using the following primers: Qa-2, Sense: $5^{\prime}$ AGGTCTTAT GGTGCTGTCAC-3', Anti sense: 5'- TGT
GTAATTCTGCTCCTTCC -3'; $\beta$-actin, Sense: 5'-TG GAATCCTGTGGCATCCATGAAAC -3', Antisense: 5'TAAAACGCAGCTCAGTAACAGTCCG-3'; IFNy, Sense: 5'-AGCGGCTGACTGAACTCAGATTGTAG CTTGTACCTTTACTTCACTG-3', Antisense: 5'-GTC ACAGTTTTCA GCTGTATAGGG-3'. Amplified PCR products were visualized on $1.2 \%$ agarose gels.

\section{Real Time PCR}

For real-time SYBR Green RT-PCR, a 20- $\mu$ l reaction containing $10 \mu \mathrm{l}$ of $2 \times$ Quantitect SYBR Green Master Mix (Qiagen, Valencia, CA, USA) was employed. The master mix was composed of hot start Taq polymerase, a $0.4 \mu \mathrm{L}$ mix of 2 reverse transcriptases, $0.5 \mu \mathrm{L}(10 \mathrm{ng} / \mu \mathrm{L})$ of template and $0.8 \mu \mathrm{L}$ of primers. An ABI $7900 \mathrm{HT}$ thermal cycler (Lab Centraal B.V., Haarlem, The Netherlands) was used for all real-time RT-PCR assays. Reverse transcription was conducted at $50^{\circ} \mathrm{C}$ for $30 \mathrm{~min}$, followed by denaturation at $95^{\circ} \mathrm{C}$ for $15 \mathrm{~min}$. DNA was amplified by subjecting the samples to 40 cycles of $95^{\circ} \mathrm{C}(30 \mathrm{~s}), 55^{\circ} \mathrm{C}$ $(30 \mathrm{~s})$, and $72^{\circ} \mathrm{C}(30 \mathrm{~s})$. Real-time RT-PCR data were collected for $15 \mathrm{sec}$ at $75^{\circ} \mathrm{C}$ to avoid non-specific fluorescence due to the formation of primer dimers at low template concentrations. For generation of standard quantitation curves, the cycle threshold values were plotted proportionally against the logarithm of the input copy numbers. Negative controls were included in each run.

\section{Qa-2 vector construction}

Qa-2 cDNA was amplified from total RNA extracted from ICR mice lymph nodes by reverse transcriptase polymerase chain reaction (RT-PCR) using the following primers: sense 5'-CGGGATCCCGATGGCTCTAACAA TGCTGC-3', antisense 5'-CGGAATTCCGCTTCGTGTGAAAGTATGGAG-3'. The sense primer included the BamH1 restriction site and the antisense primer included the EcoR1 restriction site. The cDNA was subsequently digested with BamHI and EcoRI and then inserted into eukaryotic expression vector pcDNA3.1 (Invitrogen, Carlsbad, CA, USA). Verification of the recombinant construct was performed by DNA sequencing. The empty vector pcDNA3.1 was used as a control. All plasmids were purified by two rounds of passage through Endo-Free columns (Qiagen, Chatsworth, CA, USA), as described elsewhere [28].

\section{Qa-2 vector transfection to HeLa cells}

HeLa cells were maintained in Dulbecco's modified Eagle medium (DMEM) supplemented with $2 \mathrm{mM}$ glutamine, $100 \mathrm{units} / \mathrm{ml}$ penicillin, $100 \mu \mathrm{g} / \mathrm{ml}$ streptomycin, and $5 \%$ (v/v) dextran-charcoal-treated fetal bovine serum at $37^{\circ} \mathrm{C}$ in $5 \% \mathrm{CO}_{2}$. Cells were plated at $10^{6}$ cells $/ 10 \mathrm{~cm}$ dish the day before transfection, after which they were transfected using a lipofectimine kit (Invitrogen, Paisley, UK) accord- 


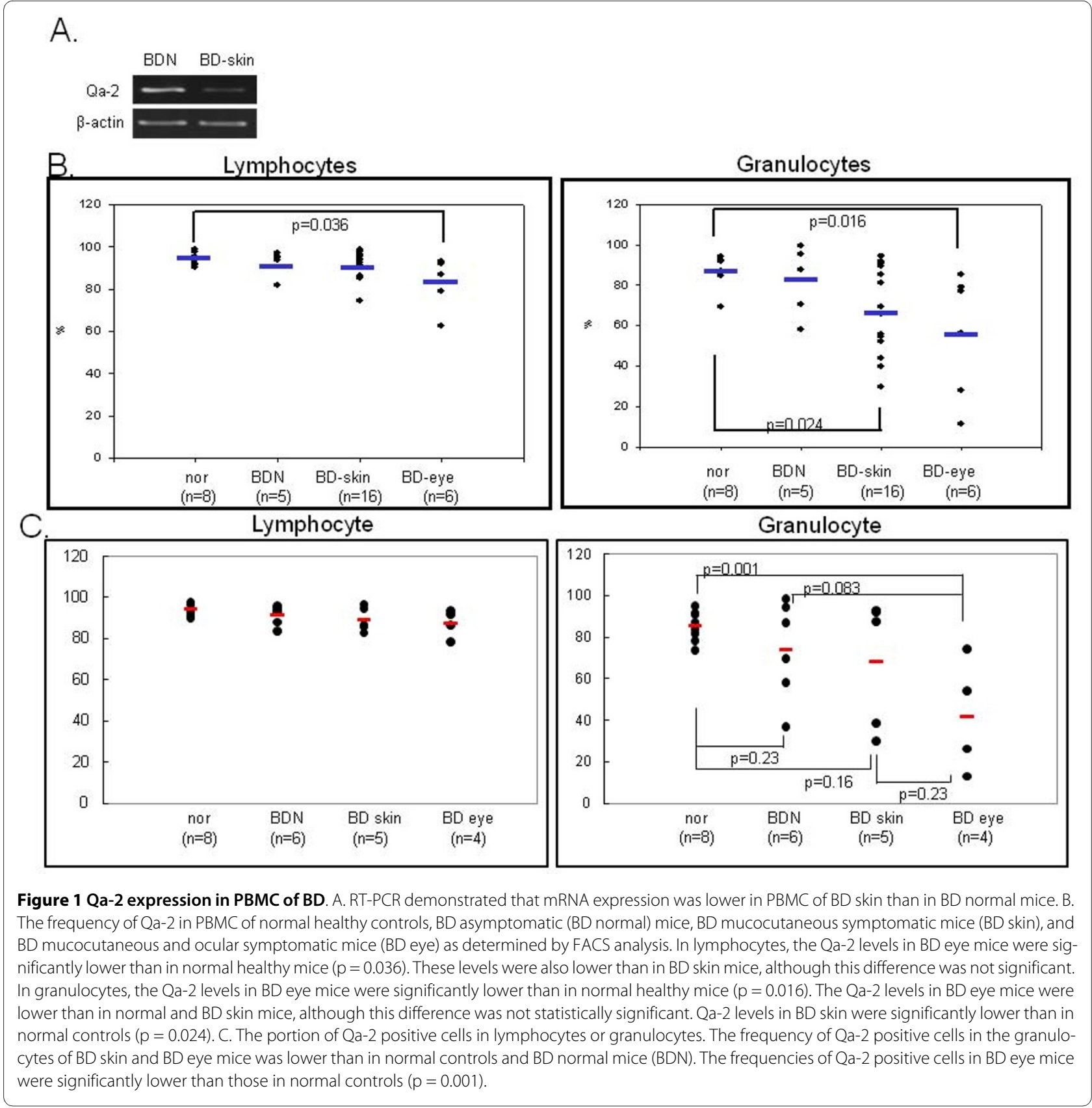

ing to the manufacturer's instructions. The vector pcDNA3.1 was transfected into HeLa cells as a control.

\section{Administration of Qa-2 vector to mice}

Normal and BD mice were intraperitoneally injected once with $50 \mathrm{ng}$ of pcDNA 3.1 or pcDNA $3.1 \mathrm{Qa}-2$ vector per mouse, and their splenocytes or macrophages were isolated three days later and analyzed by flow cytometry. Vector mixed with transfection reagent jetPEI was injected into mice and the frequency of Qa-2 protein expression was analyzed by FACS.

\section{Statistical analysis}

All data are presented as the mean \pm SE. Statistical differences between groups were determined using a Student's $t$ test and the Bonferroni correction. Statistical analysis was conducted using MedCalc version 9.3.0.0.

\section{Results}

Qa-2 mRNA and Qa-2 positive PBMCs were lower in BD symptomatic mice than in normal healthy mice

RT-PCR revealed that Qa-2 mRNA expression in peripheral blood mononuclear cells (PBMC) of mucocutaneous 

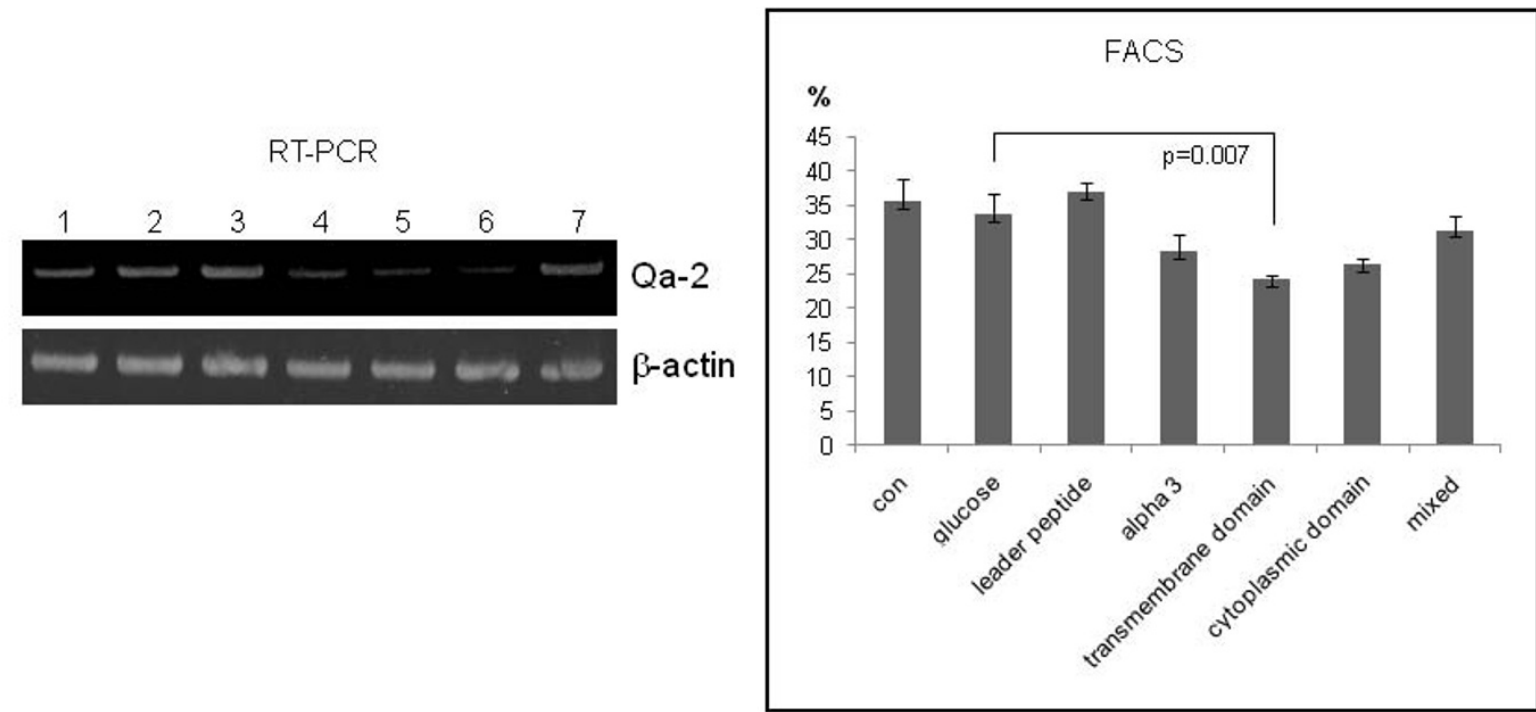

Figure 2 Qa-2 siRNA reduced Qa-2 mRNA and the frequency of Qa-2 positive cells in PBMC of normal mice. PBMC isolated from mice were transfected with Qa-2 siRNAs with different Qa-2 domains for 24 hrs, and the expression of Qa-2 was then determined by reverse transcriptase-PCR and FACS analysis. Lanes 4, 5 and 6 (a3 domain, transmembrane domain, and cytoplasmic domain, respectively) showed that siRNA effectively reduced the Qa-2 mRNA levels. Lane 3 (leader peptide) did not decrease the Qa-2 level. Lane 7 (a mixture of leader peptide, a3 domain, transmembrane domain, and cytoplasmic domain) also did not decrease the Qa-2 level. Lane 1, control (not treated); Lane 2, 5\% glucose treated; Lane 3, leader peptide 200 nmole; Lane 4, a3 domain 200 nmole; Lane 5, transmembrane domain 200 nmole; Lane 6, cytoplasmic domain 200 nmole; Lane 7, mixed 200 nmole (leader peptide + a3 domain+ transmembrane domain + cytoplasmic domain).

symptomatic BD mice was down-regulated when compared to asymptomatic BD mice, despite HSV inoculation (BD normal, BDN) (Figure 1A). Next, Qa-2 levels in PBMCs obtained from normal healthy mice, BD asymptomatic mice $(\mathrm{BDN}), \mathrm{BD}$ skin symptomatic mice (BD skin), and $\mathrm{BD}$ eye symptomatic mice (BD eye) were analyzed by flow cytometry. The symptoms of BD skin consisted of typical mucocutaneous symptoms in mice without ocular symptoms, while those of $\mathrm{BD}$ eye mice consisted of ocular symptoms with mucocutaneous symptoms. After FACS staining, lymphocytes and granulocytes were separated by gating. In lymphocytes, Qa-2 positive cells accounted for $94.78 \pm 3.56 \%$ in normal healthy mice, $92.56 \pm 6.13 \%$ in BD normal mice, $91.73 \pm$ $5.96 \%$ in BD skin, and $84.49 \pm 11.95 \%$ in BD eye mice. BD eye mice were found to have a statistically lower number of Qa-2 positive cells than normal healthy mice ( $\mathrm{p}=$ $0.036)$. In granulocytes, Qa-2 positive cells were $87.01 \pm$ $7.97 \%$ in normal healthy mice, $82.29 \pm 17.47 \%$ in BD normal mice, $67.9 \pm 21.42 \%$ in $\mathrm{BD}$ skin mice, and $56.00 \pm$ $30.49 \%$ in BD eye mice. BD skin and BD eye mice showed significantly lower levels of Qa-2 positive cells than normal healthy mice ( $\mathrm{p}=0.024, \mathrm{p}=0.016$ each) (Figure $1 \mathrm{~B})$. The portion of Qa-2 positive cells in the granulocytes of $\mathrm{BD}$ skin and $\mathrm{BD}$ eye mice was lower than that of normal control and BD normal (BDN) mice. The portion of Qa-2 positive cells in the granulocytes of $\mathrm{BD}$ eye mice was significantly lower than that of normal controls $(p=0.001)$ (Figure 1C). As shown in Figure 1, the decreased level of $\mathrm{Qa}-2$ was related to the BD symptoms.

RNA interference of Qa-2 transcription in vitro; Qa-2 siRNA reduced Qa-2 mRNA levels in PBMCs of normal mice

PBMCs isolated from normal mice were transfected for $24 \mathrm{~h}$ with Qa-2 siRNA with different domains, after which the expression of Qa-2 was determined by reverse transcriptase-PCR. siRNA for the $\alpha 3$ domain, transmembrane domain, and cytoplasmic domain inhibited the Qa2 level; however, the leader peptide domain did not. Mixed siRNA consisting of equal amounts each of these four domains did not downregulate the Qa-2 mRNA level. Flow cytometric analysis also showed a decreased frequency of Qa-2 expression in the Qa-2 siRNA domaintreated groups, except for the leader peptide domain (Figure 2).

\section{Downregulation of Qa-2 by intravenous injection of siRNA into BD mice}

Next, an siRNA mixture composed of the siRNA of the $\alpha 3$ domain, transmembrane domain and the cytoplasmic domain was injected into BD mice. Five to six individual $\mathrm{BD}$ mice in each group were intravenously injected once 


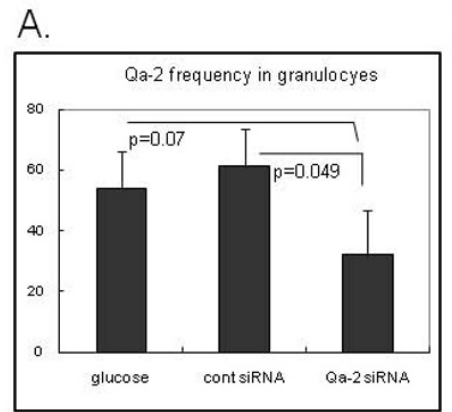

B.
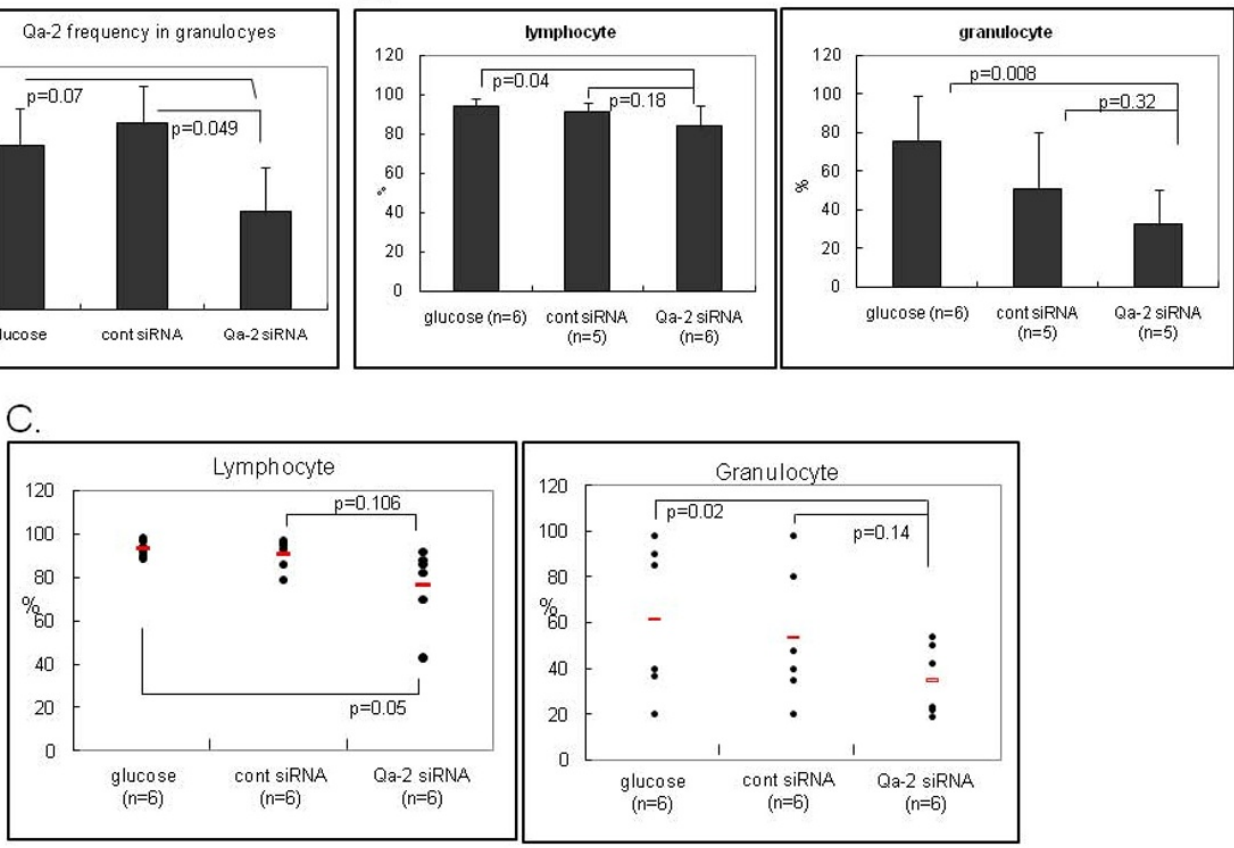

Figure 3 Down-regulation of Qa-2 after intravenous injection of siRNA into BD mice. A. BD mice were injected once with control siRNA or Qa2 siRNA ( $500 \mathrm{nmol} / \mathrm{mouse}$ ), which was composed of the a3 domain, transmembrane domain, and cytoplasmic domain. PBMC collected from the orbital sinus before and 1 day after injection were analyzed by flow cytometry. Qa-2 siRNA effectively reduced the Qa-2 levels in the PBMC of BD mice. B. Two days after injection, the frequency of Qa-2 positive lymphocytes and granulocytes was analyzed in Qa-2 siRNA injected BD mice. In lymphocytes and granulocytes, Qa-2 siRNA significantly reduced the number of Qa-2 positive cells when compared to glucose-injected control mice. C. The frequency of Qa-2 positive cells in mice that were injected with Qa-2 siRNA four times. Specifically, 500 nmol control siRNA or Qa-2 siRNA in 200 $\mu$ l of 5\% glucose solution was intraperitoneally injected four times with a three day interval between injections, and the PBMC were analyzed by FACS two days after the last injection. In lymphocytes and granulocytes, Qa-2 siRNA significantly reduced the Qa-2 positive cells when compared to glucose injected control mice.

with $5 \%$ glucose or $500 \mathrm{nmol}$ of Qa-2 siRNA or control siRNA, and their PBMCs were analyzed one day and two days later by flow cytometry. One day after Qa-2 siRNA injection, the number of $\mathrm{Qa}-2$ positive granulocytes was $32.18 \pm 14.64 \%$, which was significantly lower $(\mathrm{p}=0.049)$ than that of mice treated with $5 \%$ glucose $(54.21 \pm 1.89 \%)$

\section{Table 2: Changes in symptoms after Qa-2 siRNA injection} into BD mice

\begin{tabular}{ll}
\hline siRNA & $\begin{array}{l}\text { Deteriorated number/ } \\
\text { total number }\end{array}$ \\
\hline Qa-2 siRNA & $3 / 6$ \\
\hline Leader peptide siRNA & $1 / 6$ \\
\hline Glucose & $0 / 7$
\end{tabular}

The symptoms of $\mathrm{BD}$ mice deteriorated following treatment with Qa-2 siRNA. Qa-2 siRNA was intravenously injected into BD mice four times with a three day interval between injections. Deterioration occurred in three of six BD mice. or leader peptide $(61.32 \pm 12.27 \%)$ (Figure $3 \mathrm{~A})$. In lymphocytes, the Qa-2 positive cell counts did not differ significantly among groups. Two days later, the frequency of Qa-2 positive cells was $84.12 \pm 10.34 \%$ in Qa-2 siRNA injected mice, while it was $94.23 \pm 3.86 \%$ of glucose injected control mice in lymphocytes $(\mathrm{p}=0.029)$. In granulocytes, the frequency of Qa-2 positive cells was $42.18 \pm$ $28.40 \%$ in Qa-2 siRNA injected mice, while it was $75.65 \pm$ $23.59 \%$ in glucose injected control mice $(\mathrm{p}=0.008)$. These findings demonstrated that Qa-2 siRNA effectively reduced the frequencies of $\mathrm{Qa}-2$ positive cells in lymphocytes and granulocytes in BD mice (Figure 3B). To determine if repeated administration can reduce the $\mathrm{Qa}-2$ level more efficiently, the frequency of Qa-2 positive cells in $\mathrm{BD}$ mice that were injected with Qa-2 siRNA four times was analyzed. To accomplish this, $500 \mathrm{nmol}$ control siRNA or Qa-2 siRNA in $200 \mu \mathrm{l}$ of $5 \%$ glucose solution was intraperitoneally injected four times with a three day interval in between injections. Two days after the last injection, the PBMCs were analyzed by FACS. In lymphocytes and granulocytes, Qa-2 siRNA led to a significant reduction in Qa-2 positive cells when compared to glu- 
A.

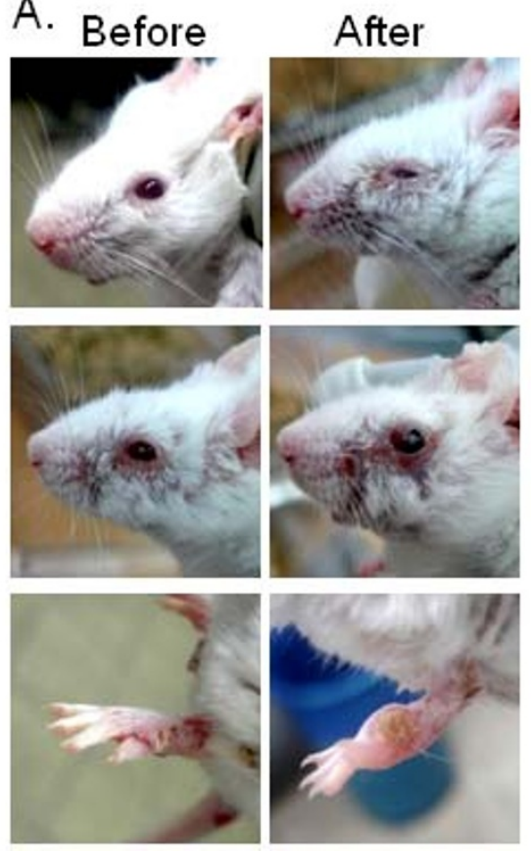

B.

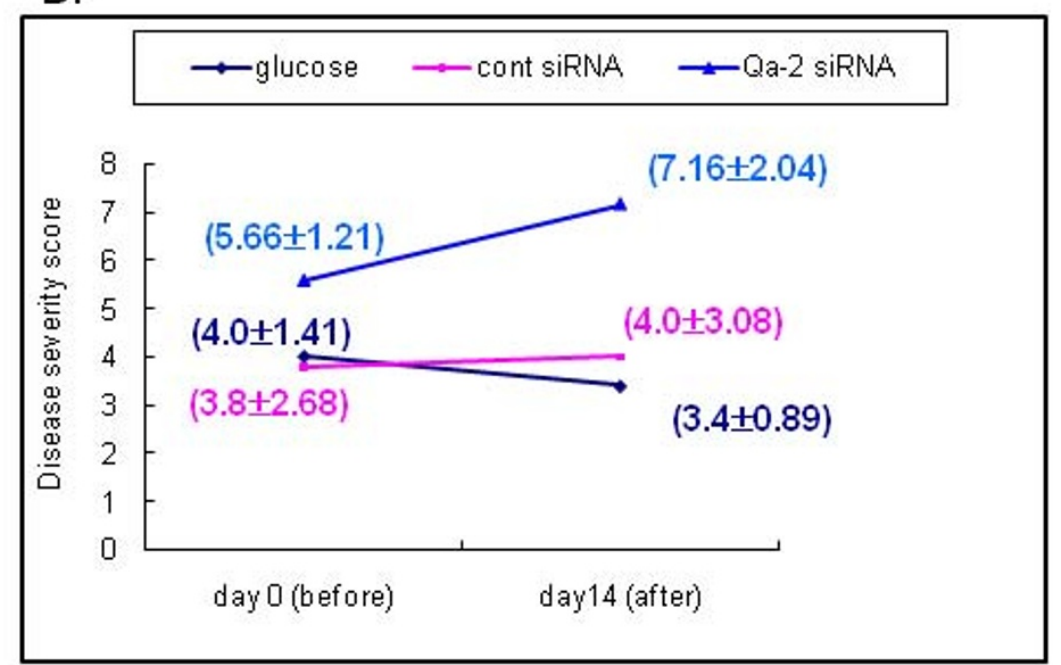

Figure 4 Qa-2 siRNA deteriorated BD symptoms. For each mouse, 500 nmol each of control siRNA or Qa-2 siRNA in 200 ml of $5 \%$ glucose solution was intraperitoneally injected four times with three day intervals, and the symptoms were photographed (A) and the severity score was analyzed (B) two days after the last injection. The severity was lower in Qa-2 siRNA injected BD mice when compared to control siRNA injected BD mice, although this change was not significant. The disease score was estimated according to the Patients Index Score, Behcet's disease current activity form 2006, ICBD. The symptoms of BD mice deteriorated after treatment with Qa-2 siRNA. Deterioration occurred in three of six BD mice (A). When treated with control siRNA, the deterioration occurred in one of six mice, while no change was observed in any of the mice injected with $5 \%$ glucose.

cose injected control mice $(\mathrm{p}=0.05, \mathrm{p}=0.02$ each) (Figure $3 \mathrm{C}$ ). However, the reduction in Qa-2 level observed in response to one and four injections did not differ significantly.

\section{The change in symptoms after Qa-2 siRNA injection into BD mice}

To determine if down-regulation of Qa-2 could influence the symptoms of BD, changes in symptoms (Table 2) and the disease severity score were examined after administration of siRNA to BD mice. Specifically, Qa-2 siRNA was intravenously injected into BD mice four times with a three day interval between treatments. After the injection of siRNA, deterioration occurred in three of six BD mice (Figure 4A). However, in mice treated with control siRNA, the deterioration only occurred in one of the six mice. In addition, there was no change in symptoms observed in any of the seven BD mice injected with 5\% glucose. The change in symptoms was scored according to the severity score of $\mathrm{BD}$, which is outlined in the BD Current Activity Form. As shown in Figure 4B, the score of the Qa-2 siRNA-injected group increased from $5.66 \pm$ 1.21 to $7.16 \pm 2.04$, although this change was not statistically significant $(p=0.07)$. In contrast, the score in the control siRNA injected group increased to $4.0 \pm 3.08$ from $3.8 \pm 2.68$, while that of the glucose injected group changed from $4.0 \pm 1.41$ to $3.4 \pm 0.89$.

\section{Qa-2 siRNA increased IFN $y$ mRNA levels in spleens of BD mice}

Recent in vitro studies have suggested that some duplex siRNA sequences have non-specific effects and can induce an IFN response, particularly at high concentrations [29,30]. However, further studies are needed to determine if these series of reactions can occur in vivo and if this can occur in response to our siRNA sequences [31]. Xie et al. reported that non-viral siRNA delivery to diseased tissue does not elicit an immune response [32]. To determine the IFNy mRNA expression, the spleen tissues of BD mice that were injected with siRNA four times were subjected to reverse transcriptase PCR (RT-PCR) (Figure 5A) and real time PCR (Figure 5B). The IFN $\gamma$ mRNA expressions were increased in the Qa-2 siRNAinjected mice when compared to the control siRNA or glucose injected group. Increased IFN $\gamma$ was not due to siRNA, but rather to suppressed Qa-2 expression because control siRNA did not increase the level of IFN $\gamma$. These findings are in accordance with the finding that HLA-Gexpressing cells showed significantly reduced levels of IFNy [33]. 


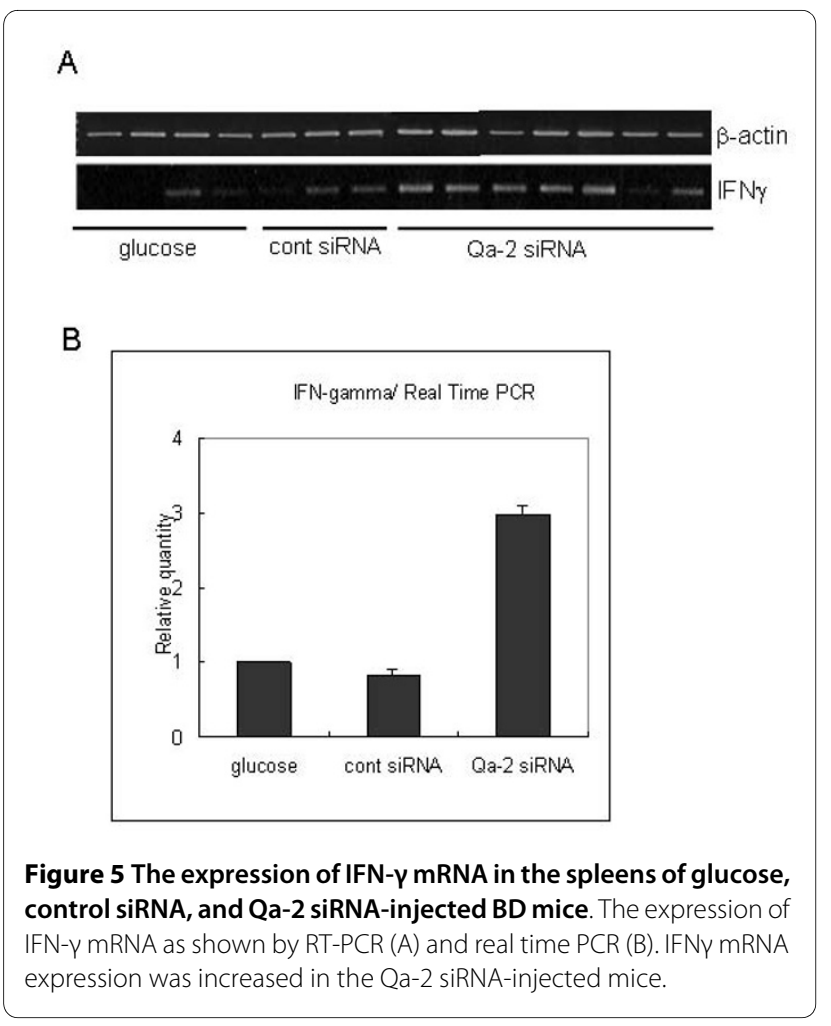

Qa-2 expression vector decreased the frequency of IFN $\gamma$ stained macrophages in BD mice

To confirm if Qa-2 could influence IFNy expression, Qa2 vector was constructed in PC3.1 vector and then administered to normal and BD mice. Cloning of the Qa-
2 gene of pGEM-Qa-2 into pcDNA3.1 vector was confirmed by digestion with EcoRI and BamHI (Figure 6A), after which the inserted sequence was confirmed by sequencing using T7 promoter (Figure 6B). The vector was intraperitoneally injected once into mice, and peritoneal macrophages and splenocytes were isolated four days later. As shown in Figure 7, the frequency of Qa-2 expressing cells in splenocytes increased to $94.53 \pm 0.64 \%$ in the Qa-2 vector injected mice, while it was $89.83 \pm$ $2.66 \%$ in control vector injected mice $(\mathrm{p}=0.45)$. Additionally, their frequency in macrophages increased to $82.25 \pm 5.62 \%$ in the Qa-2 vector injected mice, while it was $67.53 \pm 4.66 \%$ in control vector injected mice $(\mathrm{p}=$ $0.003)$. The IFNY levels in macrophages of Qa-2 vectorinjected mice also decreased to $16.60 \pm 6.11 \%$, while they were $66.24 \pm 7.28 \%$ in control mice $(\mathrm{p}<0.001)$ (Figure 8 ). Qa-2 expression vector appeared to work in macrophages, and these effects were accompanied by a decrease in IFN $\gamma$.

\section{The frequency of NK cells in BD and BDN mice}

To confirm the relationship between HLA-G and the NK cells, the frequency of NK cells was observed in BD and BDN mice using flow cytometry. As shown in Figure 9, the frequency of NK cells in splenocytes was $13.8 \pm 2.2 \%$ in $\mathrm{BD}$ mice $(\mathrm{n}=9)$ when compared to $\mathrm{BDN}$ mice $(5.4 \pm$ $0.3 \%)(\mathrm{n}=5, \mathrm{p}<0.001)$ and normal mice $(8.9 \pm 1.1 \%)(\mathrm{n}=$ $7, \mathrm{p}<0.001)$. The frequency of NK cells in BD mice was higher than BDN. These findings indicate that down-regulation of HLA-G may influence the higher frequency of NK cells in BD mice.

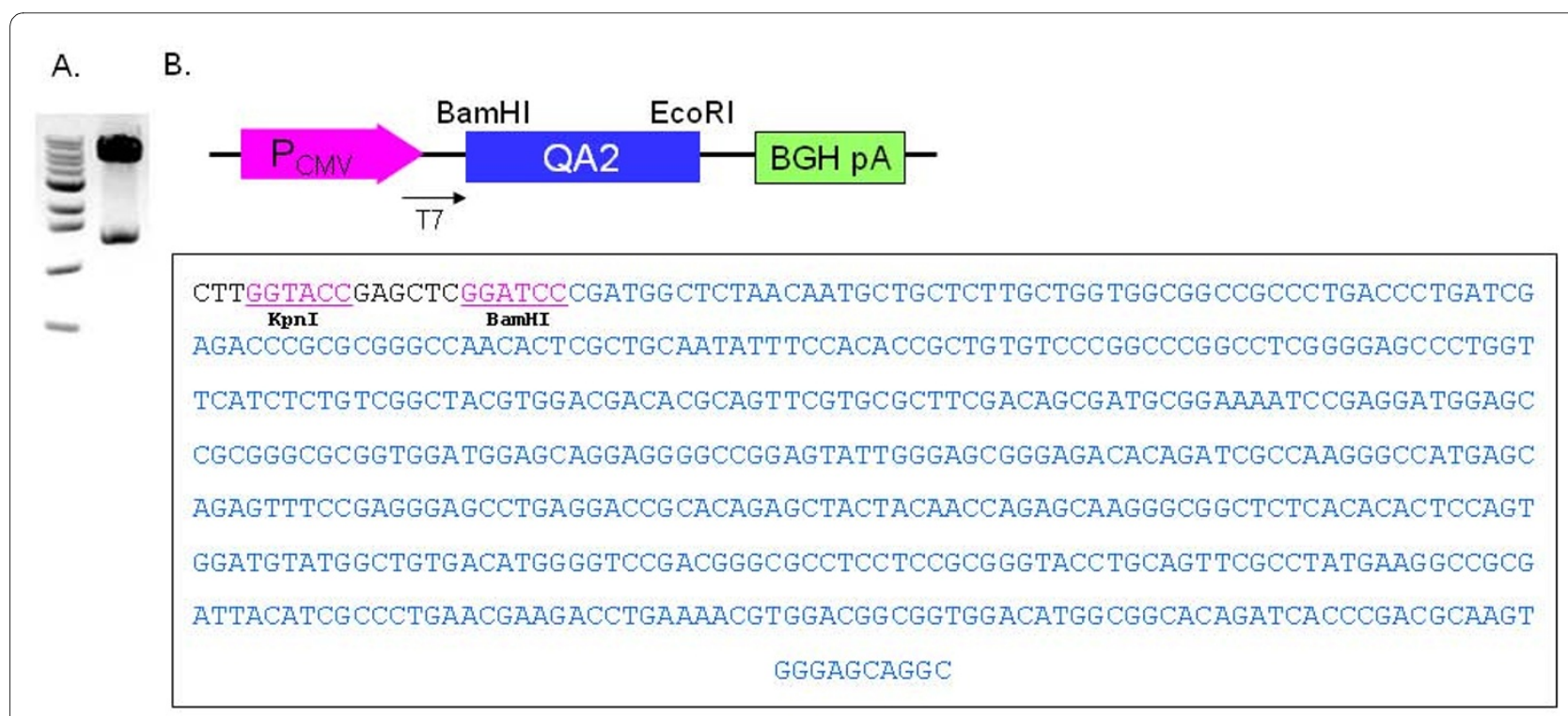

Figure 6 Construction of a Qa-2 expression vector. A. pcDNA3.1-Qa-2 was constructed by insertion of the full length mouse Qa-2 gene into the EcoR1 and BamH1 restriction site (expected size: $1.36 \mathrm{~kb}+5.43 \mathrm{~kb}$ ). The inserted Qa-2 gene was confirmed by digestion with EcoRI and BamHI. B. Vector inserted Qa-2 was sequenced using T7 promoter. 

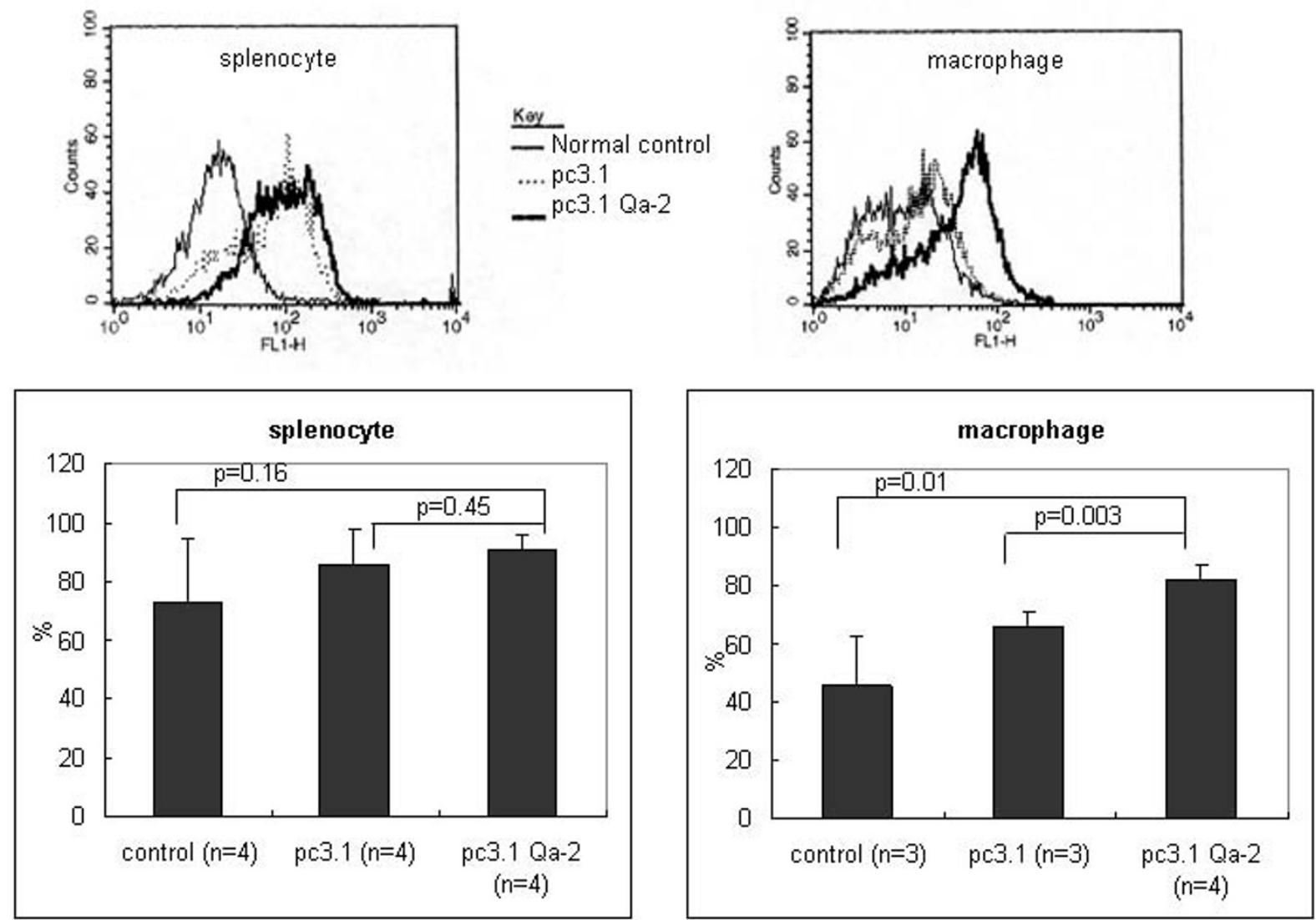

Figure 7 Expression of pc3.1DNA Qa-2 vector in vivo in normal mice. The frequency of Qa-2 protein in splenocytes and macrophages isolated from normal mice injected with $50 \mu \mathrm{g}$ pc3.1DNA Qa-2 vector as determined by FACS analysis. The macrophages isolated from mice injected with pc3.1DNA Qa-2 vector showed a higher frequency of Qa-2 positive cells when compared to the non-injected control $(p=0.01)$ and pc3.1 DNA vectorinjected mice $(p=0.003)$. The splenocytes also showed a higher frequency of Qa-2 positive cells when compared to the non-injected control and pc3.1 DNA vector injected mice, although this difference was not significant.

\section{Discussion}

In this study, Qa-2 expression in HSV-induced BD mice was investigated and compared to that of normal mice and $\mathrm{BD}$ asymptomatic mice. The number of $\mathrm{Q} a-2$ positive granulocytes in $\mathrm{PBMC}$ was lower in $\mathrm{BD}$ mice than in $\mathrm{BD}$ asymptomatic or normal healthy mice. Among BD mice, the Qa-2 frequency of PBMC in BD eye mice was lower than in BD skin mice, and the differences were larger in granulocytes than lymphocytes. mRNA expression also showed a pattern similar to the FACS frequency. Furthermore, we found that the in vivo injection of Qa-2 siRNA reduced the Qa-2 mRNA and protein levels in PBMC of $\mathrm{BD}$ mice and deteriorated BD symptoms. Taken together, these findings indicate that down-regulation of $\mathrm{Qa}-2$ could be an important factor in worsening of BD symptoms.

It has been reported that genetic variants with a 14-bp deletion polymorphism in the HLA-G region are associated with Kawasaki disease [34], juvenile idiopathic arthritis [35], ulcerative colitis, and Crohn's disease [36].
In patients with Behcet's disease, the frequency of haplotypes containing the HLA-G 3741_3754 14 base pair insertion and 1597"delC was found to increase, and this insertion was associated with a lower serum level of HLA-G [26]. In the present study, we found that Qa-2 mRNA and Qa-2 positive PBMCs were significantly lower in $\mathrm{BD}$ symptomatic mice than in normal healthy mice.

RNA interference has emerged as a powerful tool to inhibit protein expression [37], and we previously reported that TNF alpha siRNA and IL- 6 siRNA inhibited the serum protein level of TNF alpha and IL-6 in vivo in the BD mouse model $[38,39]$. In the present study, Qa-2 siRNA was found to reduce Qa-2 mRNA levels and protein expression in vitro in PBMCs isolated from normal mice, and intravenous injection of siRNA into BD mice down-regulated the frequency of Qa-2 expression in lymphocytes and granulocytes of BD mice. Treatment of BD mice with Qa-2 siRNA resulted in deterioration of symptoms such as skin ulcer and arthritis, and decreased Qa-2 

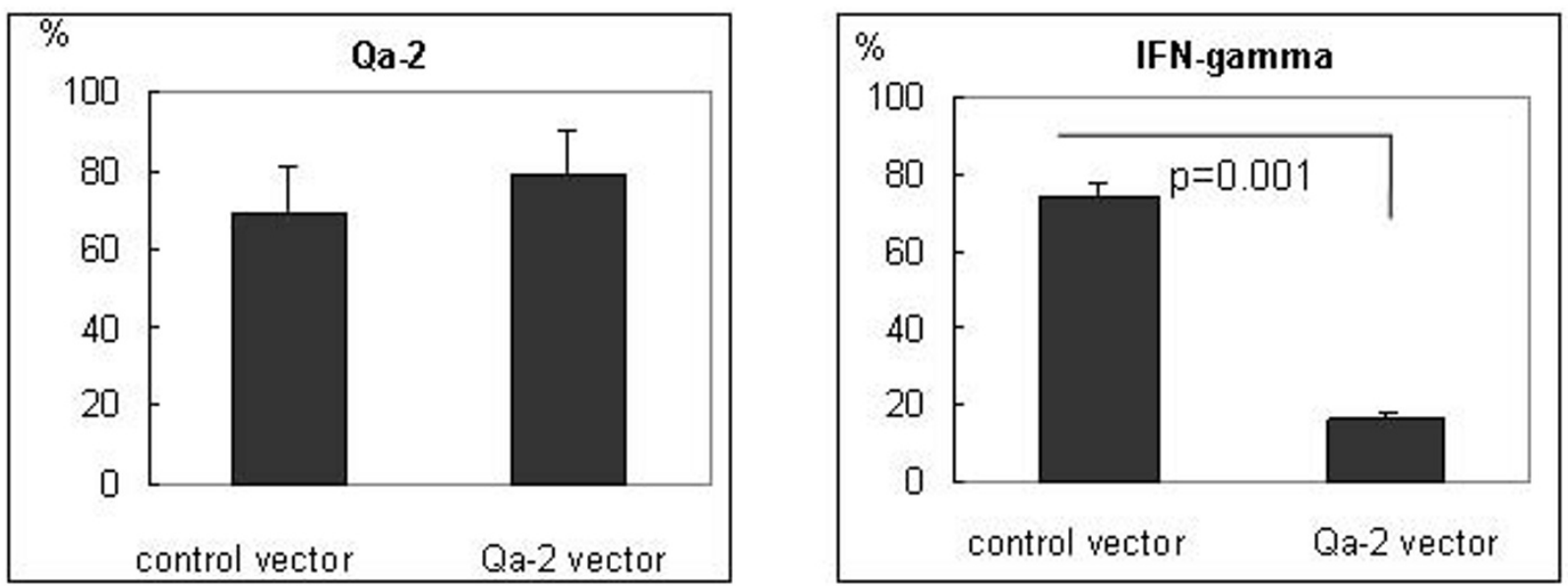

Figure 8 Expression of Qa-2 and IFNy in the macrophages of Qa-2 vector injected BD mice as shown by FACS analysis. BD mice were intraperitoneally injected once with 50 mg of pcDNA 3.1 vector or pcDNA 3.1 Qa-2 vector and their macrophages were analyzed four days later by flow cytometry. Qa-2 positive cells were increased in the Qa-2 vector injected mice, whereas IFNy positive cells decreased.

levels were found to be related to changes in the disease progression. Control siRNA injection to BD mice did not change the BD symptoms and disease severity score. The inhibitory function of HLA-G might be important in regulation of the immune responses [40].

HLA-G also influences the Th cytokine balance toward Th2 by promoting the secretion of IL-3, IL-4 and IL-10 while down-regulating the production of IFN $\gamma$ and TNF $\alpha$ [41-43]. In the present study, Qa-2 siRNA increased the IFN $\gamma$ mRNA levels in the spleens of BD mice, whereas control siRNA did not increase the IFN $\gamma$ mRNA levels. The increase in IFN $\gamma$ mRNA levels after injection of Qa-2 siRNA to BD mice was not due to a non-specific immune response, but rather to down-regulation of Qa-2. In addition, the present results showed that the injection of Qa-2

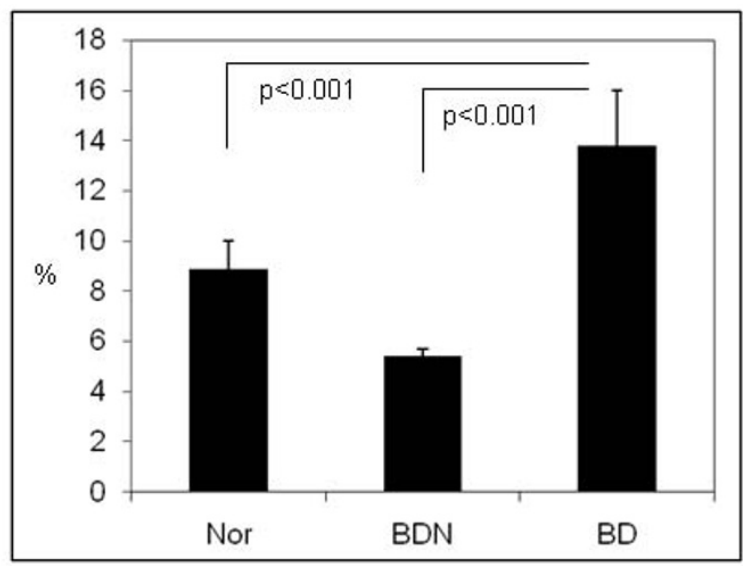

Figure 9 The frequency of NK cells in BD and BDN mice. The frequency of NK cells was analyzed in BD and BDN mice using flow cytometry. expression vector decreased IFN $\gamma$-stained macrophages in $\mathrm{BD}$ mice.

It has been suggested that genetic, immunologic and inflammatory factors play a significant role in susceptibility to BD [44]. NK cells play a role in induction and/or regulation of various types of immune responses, including several autoimmune diseases, through cytotoxicity and cytokine production [45]. Several studies have shown natural killer (NK)-mediated cytotoxicity, and cytokine secretion is believed to play roles in the immunopathogenesis of Behcet's disease [46,47]. Functionally, HLA-G directly inhibits the cytolytic function of peripheral blood NK cells [48]. The frequency of NK cells was found to be higher in BD mice than BDN mice. Increased numbers of NK cells have been reported in patients with $\mathrm{BD}$ [49]. The down-regulation of Qa-2 by siRNA might increase the number of NK cells, and the increase of NK cells might play an important role in the pathogenesis of BD.

\section{Conclusions}

Qa-2 levels were lower in the PBMC of BD mice than in the $\mathrm{PBMC}$ of normal mice. In addition, $\mathrm{Qa}-2$ levels were lower in $\mathrm{BD}$ mice with eye involvement than in $\mathrm{BD}$ mice with mucocutaneous involvement and BD asymptomatic mice. Qa-2 siRNA effectively reduced Qa-2 mRNA expression in PBMC culture and the frequency of Qa-2 positive $\mathrm{PBMC}$ in $\mathrm{BD}$ mice, indicating that $\mathrm{Qa}-2$ siRNA effectively reduced Qa-2 expression both in vitro and in vivo. Qa-2 siRNA was capable of modulating BD-like symptoms, leading to deterioration of $\mathrm{BD}$ mice. The results of this study confirmed that decreased Qa-2 levels are related to changes in the disease pattern and deterioration of $\mathrm{BD}$-like symptoms. 


\section{Competing interests}

The authors declare that they have no competing interests.

\section{Authors' contributions}

$\mathrm{ML}$ conducted the molecular and flow cytometric portions of the study, participated in the in vivo experiment, and drafted the manuscript. BC participated in the vector construction and in vitro experiment. HJK participated in making the BD mouse model. JAS conducted the experiments on the NK cells. KSP and ESL participated in the design of the study and discussion of data analysis. SS conceived of the study, participated in its design and coordination, and helped draft the manuscript. All authors read and approved the final manuscript.

\section{Acknowledgements}

This study was supported by grant No. R01-2008-000-20474-0 from the Basic Research Program of the Korea Science \& Engineering Foundation and KRF2008-531-E00024 from the Korea Research Foundation.

\section{Author Details}

'Laboratory of Cell Biology, Ajou University Institute for Medical Sciences, Suwon, Korea, ${ }^{2}$ Department of Biology, Sungshin University, Seoul, Korea, ${ }^{3}$ Department of Dermatology, Ajou University School of Medicine, Suwon, Korea and 4 Brain Korea 21 Project for Medical Science, Ajou University, Suwon, Korea

Received: 8 January 2010 Accepted: 24 June 2010

Published: 24 June 2010

\section{References}

1. Geraghty DE, Koller BH, Orr HT: A human major histocompatibility complex class I gene that encodes a protein with a shortened cytoplasmic segment. Proc Natl Acad Sci USA 1987, 84:9145-9149.

2. Ellis SA, Sargent IL, Redman CW, McMichael AJ: Evidence for a novel HLA antigen found on human extravillous trophoblast and a choriocarcinoma cell line. Immunology 1986, 59:595-601.

3. Crisa L, McMaster MT, Ishii JK, Fisher SJ, Salomon DR: Identification of a thymic epithelial cell subset sharing expression of the class Ib HLA-G molecule with fetal trophoblasts. J Exp Med 1997, 186:289-298.

4. Torres MI, Lopez-Casado MA, Luque J, Rios A: New advances in celiac disease: serum and intestinal expression of HLA-G. Int Immunol 2006, 18:713-718.

5. Rizzo R, Hviid TV, Stignani M, Balboni A, Grappa MT, Melchiorri L, Baricordi OR: The HLA-genotype is associated with IL-10 levels in activated PBMCs. Immunogenetics 2005, 57:172-181.

6. Carosella ED, Favier B, Rouas-Freiss N, Moreau P, Lemaoult J: Beyond the increasing complexity of the immunomodulatory HLA-G molecule. Blood 2008, 111:4862-70.

7. Riteau B, Rouas-Freiss N, Menier C, Paul P, Dausset J, Carosella ED: HLA-G2, -G3 and -G4 isoforms expressed as nonmature cell-surface glycoproteins inhibit NK and antigen-specific CTL cytolysis. J Immunol 2001, 166:5018-5026.

8. Rajagopalan S, Long EO: A human histocompatibility leukocyte antigen (HLA)-G-specific receptor expressed on all natural killer cells. J Exp Med 1999, 189:1093-1099.

9. Dorling A, Monk NJ, Lechler RI: HLA-G inhibits the transendothelial migration of human NK cells. Eur J Immunol 2000, 30:586-593.

10. Kanai T, Fujii T, Unno N, Yamashita T, Hyodo H, Miki A, Hamai Y, Kozuma S, Taketani Y: Human leukocyte antigen-G-expressing cells differently modulate the release of cytokines from mononuclear cells present in the decidua versus peripheral blood. Am J Reprod Immunol 2001, 45:94-99.

11. Riteau B, Menier C, Khali--Daher I, Sedlik C, Dausset J, Rouas-Freiss N, Carosella ED: HLA-G inhibits the allogeneic proliferative response. J Reprod Immunol 1999, 43:203-211.

12. Bainbridge DR, Ellis SA, Sargent IL: HLA-G suppresses proliferation of CD4+ T lymphocytes. J Reprod Immunol 2000, 48:17-26.

13. Aractingi S, Briand N, Le Danff C, Viguier M, Bachelez H, Michel L, Dubertret $L$, Carosella ED: HLA-G and NK receptor are expressed in psoriatic skin: a possible pathway for regulating infiltrating T cells? Am J Pathol 2001, 159:71-77.
14. Khosrotehrani K, Le Danff C, Reynaud-Mendel B, Dubertret L, Carosella ED, Aractingi S: HLA-G expression in atopic dermatitis. J Invest Dermatol 2001, 117:750-752.

15. Shimizu T, Ehrlich GE, Inaba G, Hayashi K: Behcet disease (Behcet syndrome). Semin Arthritis Rheum 1979, 8:223-260

16. Lee S, Bang D, Cho YH, Lee ES, Sohn S: Polymerase chain reaction reveals herpes simplex virus DNA in saliva of patients with Behçet's disease. Arch Dermatol Res 1996, 288:179-183.

17. Lee $E S$, Lee $S$, Bang $D$, et al:: Herpes simplex virus detection by polymerase chain reaction in intestinal ulcer of patients with Behcet's disease. In Proceedings of 7th International Conference on Behcet's Disease Edited by: Hamza M. Tunis: Pub Adhoua; 1997:71-73.

18. Bang D, Cho YH, Choi HJ, et al:: Detection of herpes simplex virus DNA by polymerase chain reaction in genital ulcer of patients with Behcet's disease. In Proceedings of 7th International Conference on Behcet's Disease Edited by: Hamza M. Tunis: Pub Adhoua; 1997:74-76.

19. Behcet $\mathrm{H}$ : Ueber rezidivierende, apthöse, durch ein virus verusachte geschwüre am mund, am auge und an den genitalen. Dermatol Wochenschr 1937, 36:1152-1157.

20. Sohn S, Lee ES, Bang D, Lee S: Behcet's disease-like symptoms induced by the herpes simplex virus in ICR mice. Eur J Dermatol 1998, 8:21-23.

21. Sohn S, Bang D, Lee ES, Kwon HJ, Lee SI, Lee S: Experimental studies on the antiviral agent famciclovir in Behcet's disease symptoms in ICR mice. Br J Dermatol 2001, 145:799-804

22. Sohn S, Bang D, Lee SI, Kim YA, Lee ES, Ha JY, Kim JH, Choi SY, Lee S: Combined treatment with colchicine and Herba Taraxaci (Tarazacum mongolicum Hand.-Mazz.) attenuates Behcet's disease-like symptoms in mice and influences the expressions of cytokines. Int Immunopharmacol 2003, 3:713-721.

23. Lee ES, Kim YA, Kwon HJ, Bang D, Lee S, Sohn S: Thalidomide upregulates macrophage inflammatory protein-1 in herpes simplex virusinduced Behcet's disease-like animal model. Arch Derm Res 2004, 296:175-181.

24. Frassanito MA, Dammacco R, Cafforio P, Dammacco F: Th1 polarization of the immune response in Behcet's disease: a putative pathogenetic role of interleukin-12. Arthritis Rheum 1999, 42:1967-1974.

25. Sohn S, Lee ES, Kwon HJ, Lee SI, Bang D, Lee S: Expression of Th2 cytokines decreases the development of and improves Behçet's disease-like symptoms induced by herpes simplex virus in mice. J Infect Dis 2001, 15:1180-1186.

26. Park KS, Nam JH, Lee ES, Choi JS, Bang D, Lee S: Increased risk of human leukocyte antigen-G gene variants in Behçet's disease. Clin Exp Rheumatol 2006, 24:S126-S127. Erratum in: Clin Exp Rheumatol. 2007, 25:507-508

27. Park KS, Park JS, Nam JH, Bang D, Sohn S, Lee ES: HLA-E*0101 and HLA$\mathrm{G}^{*} 010101$ reduce the risk of Behcet's disease. Tissue Antigens 2007, 69:139-144

28. Ulker N, Lewis KD, Hood LE, Stroynowski I: Activated T cells transcribe an alternatively spliced mRNA encoding a soluble form of Qa-2 antigen. EMBO J 1990, 9:3839-4387.

29. Jackson AL, Bartz SR, Schelter J, Kobayashi SV, Burchard J, Mao M, Li B, Cavet G, Linsley PS: Expression profiling reveals off-target gene regulation by RNAi. Nat Biotechnol 2003, 21:635-637.

30. Sledz CA, Holko M, de Veer MJ, Silverman RH, Williams BR: RNA interference and double-stranded-RNA-activated pathways. Biochem Soc Trans 2004, 32:952-956.

31. Hamar P, Song E, Kokeny G, Chen A, Ouyang N, Lieberman J: Small interfering RNA targeting Fas protects mice against renal ischemiareperfusion injury. Proc Natl Acad Sci USA 2004, 101:14883-14888.

32. Xie FY, Woodle MC, Lu PY: Harnessing in vivo siRNA delivery for drug discovery and therapeutic development. Drug Discov Today 2006, 11:67-73.

33. Rieger L, Hofmeister V, Probe C, Dietl J, Weiss EH, Steck T, Kämmerer U: Th1- and Th2-like cytokine production by first trimester decidual large granular lymphocytes is influenced by HLA-G and HLA-E. Mol Hum Reprod 2002, 8:255-261.

34. Kim JJ, Hong SJ, Hong YM, Kim S, Kang MJ, Kim KJ, Seo EJ, Yoo HW Cheong HS, Shin HD, Park IS, Lee JK: Genetic variants in the HLA-G region are associated with Kawasaki disease. Hum Immunol 2008, 69:867-871. 
35. Veit TD, Vianna P, Scheibel I, Brenol CV, Brenol JC, Xavier RM, DelgadoCañedo A, Gutierrez JE, Brandalize AP, Schuler-Faccini L, Chies JA: Association of the HLA-G 14-bp insertion/deletion polymorphism with juvenile idiopathic arthritis and rheumatoid arthritis. Tissue Antigens 2008, 71:440-446.

36. Glas J, Török HP, Tonenchi L, Wetzke M, Beynon V, Teshome MY, Cotofana S, Schiemann U, Griga T, Klein W, Epplen JT, Folwaczny C, Folwaczny M, Mussack T, Weiss EH: The 14-bp deletion polymorphism in the HLA-G gene displays significant differences between ulcerative colitis and Crohn's disease and is associated with ileocecal resection in Crohn's disease. Int Immunol 2007, 19:621-626.

37. Pawar RM, Raj GD, Kumar TM, Raja A, Balachandran C: Effect of siRNA mediated suppression of signaling lymphocyte activation molecule on replication of peste des petits ruminants virus in vitro. VirusResearch 2008, 136:118-123.

38. Choi B, Hwang Y, Kwon HJ, Lee ES, Park KS, Bang D, Lee S, Sohn S: Tumor necrosis factor alpha small interfering RNA decreases herpes simplex virus-induced inflammation in a mouse model. J Dermatol Sci 2008, 52:87-97.

39. Shim J, Byun HO, Lee YD, Lee ES, Sohn S: Interleukin-6 small interfering RNA improved the herpes simplex virus-induced systemic inflammation in vivo Behcet's disease-like mouse model. Gene Ther 2009, 16:415-425.

40. Trowsdale J, Betz AG: Mother's little helpers: mechanisms of maternalfetal tolerance. Nat Immunol 2006, 7:241-246.

41. Fujii T, Hamai Y, Kozuma S Miki A, Yamashita T, Hyodo H, Unno N, Taketani $Y$ : Effects of sairei-to and tokishakuyaku-san on cytokine release from peripheral blood mononuclear cells upon recognition of HLA-G protein in the treatment of recurrent abortion. Methods Find Exp Clin Pharmacol 1999, 21:261-264

42. Rieger L, Hofmeister V, Probe C Dietl J, Weiss EH, Steck T, Kämmerer U: Th1- and Th2-like cytokine production by first trimester decidual large granular lymphocytes is influenced by HLA-G and HLA-E. Mol Hum Reprod 2002, 8:255-261.

43. Carosella ED, Moreau P, Aractingi S, Rouas-Freiss N: HLA-G: a shield against inflammatory aggression. Trends Immunol 2001, 22:553-555.

44. Zierhut M, Mizuki N, Ohno S, Inoko H, Gül A, Onoé K, Isogai E: Immunology and functional genomics of Behçet's disease. Cell Mol Life Sci 2003, 60:1903-1922.

45. Carnaud C, Lee D, Donnars O, Park SH, Beavis A, Koezuka Y, Bendelac A: Cross-talk between cells of the innate immune system: NKT cells rapidly activate NK cells. J Immunol 1999, 163:4647-4650.

46. Ahn JK, Chung H, Lee DS, Yu YS, Yu HG: CD8brightCD56+ T cells are cytotoxic effectors in patients with active Behcet's uveitis. J Immunol 2005, 175:6133-6142

47. Takeno M, Shimoyama Y, Kashiwakura J, Nagafuchi H, Sakane T, Suzuki N: Abnormal killer inhibitory receptor expression on natural killer cells in patients with Behçet's disease. Rheumatol Int 2004, 24:212-216.

48. Rouas-Freiss N, Marchal RE, Kirszenbaum M, Dausset J, Carosella ED: The alpha1 domain of HLA-G1 and HLA-G2 inhibits cytotoxicity induced by natural killer cells: Is HLA-G the public ligand for natural killer cell inhibitory receptors? Proc Natl Acad Sci USA 1997, 94:5249.

49. Kaneko F, Takahashi Y, Muramatsu R, Adachi K, Miura Y, Nakane A, Minagawa T: Natural killer cell numbers and function in peripheral lymphoid cells in Behcet's disease. Br J Dermatol 1985, 113:313-318.

doi: $10.1186 / 1476-9255-7-31$

Cite this article as: Lee et al., The role of Qa-2, the functional homolog of HLA-G, in a Behcet's disease-like mouse model induced by the herpes virus simplex Journal of Inflammation 2010, 7:31

\section{Submit your next manuscript to BioMed Central and take full advantage of:}

- Convenient online submission

- Thorough peer review

- No space constraints or color figure charges

- Immediate publication on acceptance

- Inclusion in PubMed, CAS, Scopus and Google Scholar

- Research which is freely available for redistribution

Submit your manuscript at www.biomedcentral.com/submit
C BioMed Central 